\title{
Epidemiological aspects of human and canine visceral leishmaniasis in State of Alagoas, Northeast, Brazil
}

\author{
M. A. N. Rocha ${ }^{a, b, c *}$, T. J. Matos-Rocha ${ }^{a, b}$, C. M. B. Ribeiro ${ }^{a, b}$ and S. R. O. Abreu \\ ${ }^{a}$ Universidade Estadual de Ciências da Saúde de Alagoas - UNCISAL, Av. Comendador Leão, \\ CEP 57025-000, Maceió, AL, Brazil

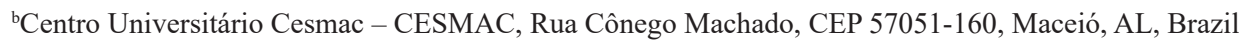 \\ 'Universidade Estadual de Alagoas - UNEAL, Rua Governador Luiz Cavalcante, s/n, Alto Cruzeiro, \\ CEP 57300-005, Arapiraca, AL, Brazil \\ *e-mail: mabelalencar@hotmail.com
}

Received: July 14, 2016 - Accepted: July 17, 2017 - Distributed: November 30, 2018

(With 1 figure)

\begin{abstract}
Zoonotic visceral leishmaniasis (ZVL), caused by protozoans of the genus Leishmania, it is a worldwide of great importance disease. In the northeast region of Brazil, the state of Alagoas has an endemic status for ZVL. Thus, this work aimed to analyze the epidemiological situation of human and canine visceral leishmaniasis in Alagoas, Northeast, Brazil, from 2007 to 2013 . We conducted a descriptive, observational, retrospective study using secondary data from the Notifiable Diseases Information System, the Center of Zoonosis Control of Maceió, and the Central Laboratory of Public Health of Alagoas. During the studied period, it was observed that the highest incidence of human visceral leishmaniasis was in 2011 and the lowest in 2013. On the other hand, canine visceral leishmaniasis had its highest incidence in 2007 and its lowest in 2012. Of the 55 municipalities in the State of Alagoas that showed human visceral leishmaniasis (HVL), São José da Tapera presented an average of 4.4 cases over the past five years, being classified as of intense transmission. Regarding canine visceral leishmaniasis, in the same studied period, 45,112 dogs were examined in the State, of which 4,466 were positive. It resulted, thus, in a $9.9 \%$ positivity rate. Conclusions: Our data are important because canine infection is an important risk factor for the human disease.
\end{abstract}

Keywords: epidemiological profile, Leishmania, Trypanosomatidae, Zoonosis.

\section{Aspectos epidemiológicos da leishmaniose visceral canina e humana no estado de Alagoas, Nordeste, Brasil}

\section{Resumo}

Leishmaniose visceral zoonótica, causada por protozoários do gênero Leishmania, é uma doença importante no mundo. Na região nordeste do Brasil, do estado de Alagoas é endêmico para LVZ. Neste sentido, este trabalho teve como objetivo analisar a situação epidemiológica da leishmaniose visceral humana e canina em Alagoas, Nordeste, Brasil, no período de 2007 a 2013. Foi realizado um estudo descritivo, observacional, retrospectivo, usando-se secundário do Sistema de Informação de Agravos de Notificação (SINAN), Centro de Controle de Zoonoses de Maceió (CCZ) e Laboratório Central de Saúde Pública de Alagoas (LACEN/AL). Durante o período de estudo, observou-se que o ano de maior incidência de Leishmaniose visceral humana (LVH) foi o de 2011 e o de menor foi no ano de 2013. Já a LVC teve maior incidência em 2007 e menor em 2012. Dos 55 municípios do Estado de Alagoas que apresentaram LVH, São José da Tapera apresentou uma média de casos de 4,4 nos últimos cinco anos classificado como de transmissão intensa; No que diz respeito à leishmaniose visceral canina (LVC), no mesmo período de estudo, foram examinados 45.112 cães no Estado, dos quais 4.466 foram positivos. Resultou assim, em uma taxa de 9,9\% de positividade. Nossos dados são importantes porque a infecção canina é um importante fator de risco para a doença humana.

Palavras-chave: perfil epidemiológico, Leishmania, Trypanosomatidae, Zoonose.

\section{Introduction}

Visceral leishmaniasis (VL) is a disease of chronic evolution that could be fatal if left untreated. Human visceral leishmaniasis (HVL) was first described in the
Americas in 1913 and in Brazil in 1936. According to the World Health Organization (WHO) 2015 report, it is considered a neglected and emerging disease, with endemic 
status in 98 countries with $90 \%$ of cases concentrated in Bangladesh, Nepal, Sudan, India, and Brazil (Peter, 2015).

Over the last 30 years, the Brazilian Northeast has shown a wide transmission of VL which is reported in several counties, indicating the Northeast as the main endemic region of Brazil. Visceral leishmaniasis is of great epidemiological importance in Alagoas, which can be seen in a published study where an epidemiological profile demonstrates the cases of lethality related to VL in Alagoas (Reis et al., 2017).

In the last ten years, there was an increase in lethality in several regions of the country, ranging from $3.4 \%$ in 1994 to $5.7 \%$ in 2009 . Lethality is higher in malnourished children, which develop more severe clinical manifestations, and has been affecting an emerging number of individuals infected by the human immunodeficiency virus (HIV) (Brasil, 2013; Souza et al., 2014).

The State of Alagoas, geographically located in the Northeast region, has a population of approximately $3,120,494$, with a population density of 112.33 people per $\mathrm{km}^{2}$ distributed in 102 municipalities (Instituto Brasileiro de Geografia e Estatística, 2010).

$\mathrm{VL}$, that at first was only present and transmitted in rural areas, has expanded to urban centers, both in domestic areas (Alvar et al., 2012). The geographical distribution is due to disorderly urbanization, poverty, human migration, deforestation and adaptation of the vector to new places (Furlan, 2010).

From an epidemiological point of view, Canine Visceral Leishmaniasis (CVL), also known as Kalazar, is more prevalent than the disease in humans. In addition, CVL features a large contingent of infected animals with cutaneous parasitism, which in its time serve as a source of infection for insect vectors (Reguera et al., 2016).

According to the literature, a cure for CVL has not yet been described. Dogs diagnosed as infected through parasitological and/or serological tests must be immediately removed from society and eliminated through euthanasia in view of their potential to be reservoirs of protozoa (Costa, 2008). In men, despite the existence of treatment, it is only possible to treat with an early diagnosis followed by appropriate recommendations (Rey et al., 2005).

VL is a severe systemic disease caused by protozoa of the genus Leishmania and transmitted by the hematophagous phlebotomine insect of the genus Lutzomyia. It presents an heteroxenic cycle, strictly intracellular, that infects cells of the Mononuclear Phagocytic System (MPS) of various animal species (Silva et al., 2008).

The incubation period of the parasite varies depending on host susceptibility. In humans, it occurs from 10 to 24 months with the following symptoms: fever, hepatosplenomegaly, anemia, paleness, weight loss, dry cough and protein-caloric malnutrition, showing pancytopenia and secondary infections (Barbosa and Costa, 2013). The incubation period varies from three months to several years in dogs, where skin lesions, ulcers, cachexia, peeling, onychogryphosis, alopecia, apathy and locomotion problems can be observed. In advanced stages, the disease reaches liver, spleen and kidneys, which leads the animal to death (Gonçalves, 2013). A published study demonstrates an historical series of patients with visceral leishmaniasis that were treated with meglumine antimoniate in a hospital for tropical diseases of Maceió-AL (Silveira et al., 2015).

There is no vaccine against human leishmaniasis and measures to fight the disease are based on the control of vectors and reservoirs, individual protection, early diagnosis and treatment of patients, environmental management, and health education (Kamphorst et al., 2015).

Current strategies to control CVL and VL are still inefficient. Considering the epidemiological features and the knowledge about the several elements that make up the chain of transmission of VL, the control is centered on the diagnosis and early treatment of human cases, surveillance, monitoring and control of vectors and reservoirs. Besides information, education and communication aimed to alert the general population and the awareness of health professionals are also included as control measures (Brasil, 2011).

The control of VL must be performed strategically through the identification of risk areas, and alternatives such as the serological canine survey, based on epidemiological criteria, are methods still recommended for combat and surveillance.

Therefore, in view of VL status in the city of Maceió and its endemic condition in the State, this work aimed to analyse the epidemiological aspects of human and canine visceral leishmaniasis in Alagoas, Northeast, Brazil, from 2007 to 2013.

\section{Material and Methods}

This was a descriptive, observational, retrospective study through the use of human secondary data from the Notifiable Diseases Information System (SINAN) provided by the Alagoas State Department of Health-SESAU/AL, canine inquiries by the Center of Zoonosis Control of Maceió (CCZ) and by the Central Laboratory of Public Health of Alagoas (LACEN/AL) and entomological reports from the Center of Zoonosis Control of Maceió.

All reported cases of HVL and CVL from 2007 to 2013 in the State of Alagoas, Brazil, were included in the present study. This period comprised a total of 231 cases of HVL and 4.466 cases of CVL. This study was approved by the Research Ethics Committee on May 27, 2014 with the identification number 658.147.

On HVL data survey, the following outcomes were analysed: age, gender, immunodepression, occupation, area of residence, income, and evolution of the case.

For statistical analysis, data were allocated on spread sheets in the 2010 Microsoft Excel ${ }^{\circledR}$ software and outcomes were analysed using the BioEstat ${ }^{\circledR}$ version 5.0 software. For inferential analysis, the G Test for contingency tables was used as well as the Chi-square Test - both considered as significant a $\mathrm{p}$ value $\leq 0.05$.

\section{Results}

This study showed that of the 102 counties in the State of Alagoas, $55(53.9 \%)$ presented at least one case of HVL, being reported 231 cases in humans and 4.466 canine 
cases of CVL by SESAU. After analysis of individual data sheets from SINAN, 225 cases of HVL were accounted. The cases of Canine leishmaniasis were notified in same municipalities of human cases of disease

One can observe that 2011 was the year with the highest incidence of HVL and 2013 was the year with the lowest incidence. On the other hand, CVL had its highest incidence in 2007 and its lowest in 2012.

Of the 55 counties in the State of Alagoas with reported cases of HVL, São José da Tapera showed an average of 4.4 cases over the past five years classified, thus, as of intense transmission; Palmeira dos Índios showed an average of 2.8 cases, classified, thus, as of moderate transmission, and the other 53 counties with an average of 2.4 , were categorized as of sporadic transmission. The Figure 1, shows the number of cases notified of illness in dogs and humans over the years analyzed.

Regarding HVL, the male gender was more affected with 148 cases $(65.3 \%)$. The age groups with the highest number of affected individuals were children, with 149 cases (66.22\%), and adults between $19-59$ years, with 70 cases

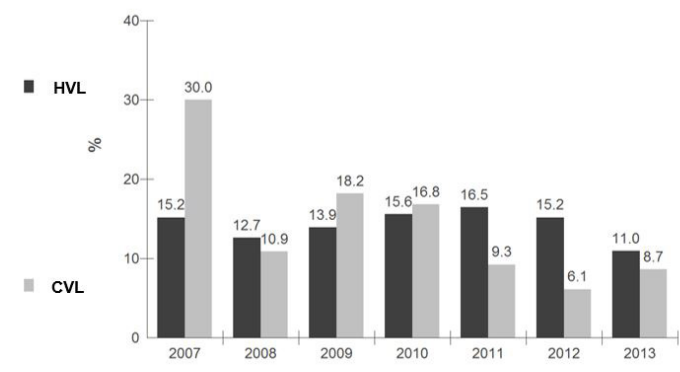

Figure 1. Cases of human visceral leishmaniasis (HVL) and canine visceral leishmaniasis (CVL) in Alagoas from 2007 to 2013.
(31.11\%). With regards to immunodepression, 94 individuals $(41.8 \%)$ were immunodepressed (Table 1$)$. At the age of 60 years is possible to notice that more people died due to the disease than healed.

Regarding the evolution of the cases, it was observed that the cure rate was of $35.11 \%$ (79 individuals); the number of deaths was of 17 individuals $(7.6 \%)$, the transfer rate was of $13.8 \%$ (31 individuals), and the amount of data sheets without answer (form sent in white) was of 87 (38.7\%). In the State of Alagoas, VL is characterized as a disease of rural transmission in view that 153 individuals $(68 \%)$ were from the countryside and $72(32 \%)$ were from the urban zone. As for the basic income, 162 individuals (72.44\%) received less than the minimum wage and 62 people $(27.56 \%)$ received one more salary (Table 2 ).

Maceió, Alagoas State capital, was the only county where the epidemiological surveillance performed a work involving the three epidemiological chain links in the studied period. Of the 50 neighbourhoods of the city, eight (16\%) presented 13 cases of HVL and 32 neighbourhoods (64\%) presented 808 cases of CVL. The entomological survey was performed only in neighbourhoods with human and/or canine cases, with 1,079 copies of Lutzomyia longipalpis (vector) in the studied period.

From 2007 to 2013 , 45,112 dogs were examined in the State, were 4,466 of which were serum-positive for CVL. Thus, a positivity rate of $9.9 \%$ was obtained. In Maceió, from 2007 to 2013,808 positive dogs were reported, of which only 176 dogs $(21.8 \%)$ went through euthanasia and $632(78.2 \%)$.

\section{Discussion}

In Brazil, the prevalence of CVL ranges from $4 \%$ to $75 \%$ depending on the assessed region and the diagnostic method used (Coura-Vital et al., 2011). The present study

Table 1. Outcomes of infection by human visceral leishmaniasis cases in Alagoas from 2007 to 2013.

\begin{tabular}{|c|c|c|c|c|c|c|c|c|c|}
\hline \multirow{3}{*}{ Gender } & \multicolumn{8}{|c|}{ Age Group } & \multirow{3}{*}{ p-value } \\
\hline & \multicolumn{2}{|c|}{0 - 11} & \multicolumn{2}{|c|}{$12-18$} & \multicolumn{2}{|c|}{$19-59$} & \multicolumn{2}{|c|}{$>60$} & \\
\hline & $\mathbf{N}$ & $\%$ & $\mathbf{N}$ & $\%$ & $\mathbf{N}$ & $\%$ & $\mathbf{N}$ & $\%$ & \\
\hline Male & 64 & 53.78 & 23 & 76.67 & 56 & 80 & 4 & 66.67 & 0.0012 \\
\hline Female & 55 & 46.22 & 7 & 23.33 & 14 & 20 & 2 & 33.33 & \\
\hline TOTAL & 119 & 100 & 30 & 100 & 70 & 100 & 6 & 100 & \\
\hline \multicolumn{10}{|c|}{ Immunodepression } \\
\hline Yes & 82 & 68.91 & 0 & 0 & 12 & 17.14 & 0 & 0 & $<0.0001$ \\
\hline No & 37 & 31.09 & 30 & 100 & 58 & 82.86 & 6 & 100 & \\
\hline TOTAL & 119 & 100 & 30 & 100 & 70 & 100 & 6 & 100 & \\
\hline \multicolumn{10}{|l|}{ Evolution } \\
\hline Cure & 40 & 33.61 & 13 & 43.333 & 24 & 34.29 & 2 & 33.33 & \\
\hline Abandonment & 1 & 0.84 & 1 & 3.33 & 0 & 0 & 0 & 0 & 0.0018 \\
\hline Death /VL & 5 & 4.20 & 1 & 3.33 & 8 & 11.43 & 3 & 50 & \\
\hline Death /other & 1 & 0.84 & 0 & 0 & 7 & 10 & 1 & 16.67 & \\
\hline Transfer & 21 & 17.65 & 4 & 13.33 & 6 & 8.57 & 0 & 0 & \\
\hline Without answer & 51 & 42.86 & 11 & 36.67 & 25 & 35.71 & 0 & 0 & \\
\hline TOTAL & 119 & 100 & 30 & 100 & 70 & 100 & 6 & 100 & \\
\hline
\end{tabular}

$\mathrm{G}$ test for contingency tables. 
Table 2. Evolution of human visceral leishmaniasis cases in Alagoas from 2007 to 2013.

\begin{tabular}{|c|c|c|c|c|c|c|c|c|c|c|c|c|c|}
\hline \multirow{3}{*}{ Year } & \multicolumn{12}{|c|}{ Evolution } & \multirow{3}{*}{ p-value } \\
\hline & \multicolumn{2}{|c|}{ Cure } & \multicolumn{2}{|c|}{ Abandonment } & \multicolumn{2}{|c|}{ Death/VL } & \multicolumn{2}{|c|}{ Death/other } & \multicolumn{2}{|c|}{ Transfer } & \multicolumn{2}{|c|}{$\begin{array}{l}\text { Without } \\
\text { answer }\end{array}$} & \\
\hline & $\mathbf{N}$ & $\%$ & $\mathbf{N}$ & $\%$ & $\mathbf{N}$ & $\%$ & $\mathbf{N}$ & $\%$ & $\mathbf{N}$ & $\%$ & $\mathbf{N}$ & $\%$ & \\
\hline 2007 & 12 & 15.19 & 0 & 0 & 4 & 23.53 & 0 & 0 & 15 & 48.39 & 3 & 3.45 & \\
\hline 2008 & 9 & 11.39 & 0 & 0 & 2 & 11.76 & 0 & 0 & 15 & 48.39 & 2 & 2.30 & $<0.0001$ \\
\hline 2009 & 12 & 15.19 & 0 & 0 & 3 & 17.66 & 2 & 22.22 & 0 & 0 & 14 & 16.10 & \\
\hline 2010 & 12 & 15.19 & 0 & 0 & 2 & 11.76 & 1 & 11.12 & 0 & 0 & 19 & 21.84 & \\
\hline 2011 & 15 & 18.99 & 1 & 50 & 2 & 11.76 & 2 & 22.22 & 1 & 3.22 & 16 & 18.39 & \\
\hline 2012 & 13 & 16.46 & 1 & 50 & 4 & 23.53 & 2 & 22.22 & 0 & 0 & 16 & 18.39 & \\
\hline 2013 & 6 & 7.59 & 0 & 0 & 0 & 0 & 2 & 22.22 & 0 & 0 & 17 & 19.54 & \\
\hline
\end{tabular}

$\mathrm{G}$ test for contingency tables.

showed a positivity of $9.99 \%$ for the 4,466 examined dogs for CVL in the State of Alagoas and $18 \%$ for the dogs in Maceió. In Maceió, only 176 dogs (21.8\%) were euthanized and $632(78.2 \%)$ dogs were pending due to lack of transport and anaesthetic.

The study could highlight that, in Alagoas, VL presented a different behaviour in infected humans and dogs. A significant reduction was verified in the percentage of infected dogs, ranging from $30.0 \%$ in 2007 to $6.1 \%$ in 2012. According to Barata et al. (2011), the reduction of CVL may have occurred due to the euthanasia recommended by the Visceral Leishmaniasis Control Program (VLCP). On the other hand, the HVL index suffered a small variation over the same period, ranging from $16.5 \%$ in 2011 to $11.0 \%$ in 2013. This may indicate a lack of early diagnosis or failure in epidemiological surveillance (Glória, 2006).

Several factors can explain the emergence of cases of HVL and CVL in the 55 reported counties in Alagoas, such as: precarious conditions of housing, lack of sanitation, problems in water supply, low income, accumulation of garbage around the residence, residences near woods or in places associated with the breeding of domestic animals, chicken coops and styes. According to Scandar et al. (2011), the transmission is facilitated by such aspects due to the increasing of vector breeding areas by presenting a sufficient amount of organic material. Hence, 153 cases $(68 \%)$ took place in the countryside and only 72 cases $(32 \%)$ occurred in the urban area.

The data from the present study showed a male dominance of cases in Alagoas, represented by 148 individuals (65.7\%), a fact that corroborates with Alvarenga et al. (2010) which observed 76 adult patients in the city of Mato Grosso do Sul, of which $74.7 \%$ were men. Góes et al. (2012) state that the hormonal factor and the factors related to vector exposure would be responsible for the increased risk in this gender. However, the study of Xavier-Gomes et al. (2009) with 51 children from a municipality of Minas Gerais showed that $51 \%$ of them were female. Regarding the research, two age groups were more affected, the children until 11 years old, and adults from 19 to 59 years old (Cavalcante and Vale, 2014).

In our study was seen high mortality by CVL on the elderly. Articles de Araújo et al. (2012), Góes et al. (2012) and Madalosso et al. (2012), fatality rates were raised by $L V$, with $24.4 \%$ variation to $69 \%$ between people aged $\geq 60$ years, but that contrasts with the poverty of the literature on clinical information during this period of life of imunosenescência of LV.

Data from the literature highlight that children are susceptible to VL due to the state of relative immaturity of immune cells exacerbated by malnutrition, especially the protein-caloric (DPC) (Miranda, 2008). Malafaia (2010) states that the DPC associated with VL kills millions of children around the world, which constitutes a serious public health issue. Missawa and Borba (2009) added that the high incidence of VL suggests that the occurrence of infection occurred in the intradomiciliary and peridomiciliary environments.

According to Oliveira et al. (2008) and Lindoso et al. (2006) the main factors that contribute to the increased lethality are the late diagnosis and the expansion of the disease affecting patients with comorbidities, with infectious and haemorrhagic complications as the main risk factors for death in VL. In this study, 12 individuals showed an HIV-VL co-infection, which increases lethality.

During the evolution of cases in Alagoas, it was observed that the index "without response" from the SINAN data sheet was represented by 87 cases $(38.7 \%)$. This constitutes an aggravating factor since the evolution of the disease cannot be identified. The identified transfer rate of 31 cases $(13.8 \%)$ stands out, where the patients destination was not informed. Hence, there were 118 cases (52.4\%) with unknown evolution. This occurred due to the limitations of a retrospective study, with secondary data, where failures on data sheet filling were observed, these issues were highlighted by other researchers (Miranda, 2008).

In Alagoas, VL is characterized as a condition of rural transmission, with $68 \%$ from the countryside and $32 \%$ from the urban area, corroborating the data of Gloria (2006). It demonstrated to be a socioeconomic problem, since $72.44 \%$ received less than the minimum wage and $27.56 \%$ received one more salary.

In Alagoas, the training of health agents to fight VL's vector started only in 2011. However, most of the 55 counties that trained their health agents had not yet started their fieldwork to fight the vector by the year of 2014 . 
The neighbourhoods of the state capital with reported cases of HVL and/or CVL were the most populous and peripherals of the city, without sanitation, with problems in water supply, inefficient garbage collection, presence of debris and low socioeconomic power. Thus, these environments are suitable for VL's vector proliferation.

According to Fernández et al. (2010), it is estimated that the chance to infect an area without sewage network or garbage collection can be 4 to 6 times greater than that in areas with an adequate health service. A survey by the Institute Trata Brazil (ITB) based on the National Information System on Sanitation (SNIS) reported that Maceió holds the 76th place in the ranking of worst indexes of basic sanitation, which can justify the number of cases of VL in the state capital (Sistema Nacional de Informação sobre Saneamento, 2012).

In this survey, the predominant species was Lutzomyia longipalpis, which stands out in the entire national scene as the most prevalent in most of the other studies (Costa et al., 2013). In 2010, the CCZ of Maceió did not perform an entomological survey due to administrative issues involving the state and municipal managements, such as the lack of traps and chemicals used to identify vector species, increasing the population risk of infection.

According to the VLCP, they must be eliminated (euthanasia) for not only being the main reservoir of the disease, but also because canine infection precedes the occurrence of human cases (Prado et al., 2011). Silva et al. (2005) state that this strategy would reduce the cases in humans. On the other hand, there are those who defend the animal rights and are against their elimination.

\section{Conclusion}

The epidemiological study is a crucial factor for an effective planning of strategies to control VL. Thus, a comprehensive control is required over the canine population and surveillance strategies should be intensified. Our data are important because canine infection is an important risk factor for the human disease in the state of Alagoas.

\section{REFERENCES}

ALVAR, J., VÉLEZ, I.D., BERN, C., HERRERO, M., DESJEUX, P., CANO, J., JANNIN, J., BOER, M., and WHO Leishmaniasis Control Team, 2012. Leishmaniasis worldwide and global estimates of its incidence. PLoS One, vol. 7, no. 5, pp. e35671. PMid:22693548. http://dx.doi.org/10.1371/journal.pone.0035671.

ALVARENGA, D.G., ESCALDA, P.M., COSTA, A.S. and MONREAL, M.T., 2010. Leishmaniose visceral: estudo retrospectivo de fatores associados à letalidade. Revista da Sociedade Brasileira de Medicina Tropical, vol. 43, no. 2, pp. 194-197. PMid:20464152. http://dx.doi.org/10.1590/S0037-86822010000200017.

ARAÚJO, V.E., MORAIS, M.H., REIS, I.A., RABELLO, A. and CARNEIRO, M., 2012. Early clinical manifestations associated with death from visceral leishmaniasis. PLoS Neglected Tropical Diseases, vol. 6, no. 2, pp. e1511. PMid:22347514. http://dx.doi. org/10.1371/journal.pntd.0001511.
BARATA, R.A., SILVA, J.C., SILVA, J.C., ALMEIDA, S.N., TEIXEIRA, L.A. and DIAS, E.S., 2011. Controle da leishmaniose visceral no município de Porteirinha, estado de Minas Gerais, no período de 1998 a 2003. Revista da Sociedade Brasileira de Medicina Tropical, vol. 44, no. 3, pp. 386-388. PMid:21779679. http://dx.doi.org/10.1590/S0037-86822011000300025.

BARBOSA, I.R. and COSTA, I.C.C., 2013. Clinical and epidemiological aspects of visceral leishmaniasis in children up to 15 years of age in Rio Grande do Norte state, Brazil. Revue des Sciences Médicales, vol. 23, no. 1, pp. 5-11.

BRASIL. Ministério da Saúde. Secretaria de Vigilância em Saúde. Departamento de Vigilância Epidemiológica, 2013. Manual de Vigilância e Controle da leishmaniose visceral. Brasília: Ministério da Saúde.

BRASIL. Ministério da Saúde. Secretaria de Vigilância em Saúde. Departamento de Vigilância Epidemiológica, 2011. Leishmaniose visceral: recomendações clínicas para diminuição da letalidade. Brasília: Ministério da Saúde.

CAVALCANTE, I.J.M. and VALE, M.R., 2014. Aspectos epidemiológicos da leishmaniose visceral (calazar) no Ceará no período de 2007 a 2011. Revista Brasileira de Epidemiologia, vol. 17, no. 4, pp. 911-924. PMid:25388491. http://dx.doi. org/10.1590/1809-4503201400040010.

COSTA, C.H.N., 2008. Characterization and speculations on the urbanization of visceral leishmaniasis in Brazil. Cadernos de Saude Publica, vol. 24, no. 12, pp. 2959-2963. PMid:19082289. http://dx.doi.org/10.1590/S0102-311X2008001200027.

COSTA, P.L., DANTAS-TORRES, F., SILVA, F.J., GUIMARÃES, V.C., GAUDÊNCIO, K. and BRANDÃO-FILHO, S.P., 2013. Ecologia de Lutzomyia longipalpis em área de transmissão de leishmaniose visceral no nordeste do Brasil. Acta Tropica, vol. 126, no. 2, pp. 99-102. PMid:23369878. http://dx.doi.org/10.1016/j. actatropica.2013.01.011.

COURA-VITAL, W., MARQUES, M.J., VELOSO, V.M., ROATT, B.M., AGUIAR-SOARES, R.D., REIS, L.E., BRAGA, S.L., MORAIS, M.H., REIS, A.B. and CARNEIRO, M., 2011. Prevalence and factors associated with Leishmania infantum infection of dogs from in urban área of Brasil as identified by moledular methods. PLoS Neglected Tropical Diseases, vol. 5, no. 8, pp. e1291. PMid:21858243. http://dx.doi.org/10.1371/ journal.pntd.0001291.

FERNÁNDEZ, M.S., SALOMÓN, O.D., CAVIA, R., PEREZ, A.A., ACARDI, S.A. and GUCCIONE, J.D., 2010. Lutzomyia longipalpis spatial distribution and association with environmental variables in an urban focus of visceral leishmaniasis, Misiones, Argentina. Acta Tropica, vol. 114, no. 2, pp. 81-87. PMid:20096256. http://dx.doi.org/10.1016/j.actatropica.2010.01.008.

FURLAN, M.B.J., 2010. Epidemia de Leishmaniose Visceral no Município de Campo Grande-MS, 2002 a 2006. Epidemiologia e Serviços de Saúde, vol. 19, no. 1, pp. 15-24.

GLÓRIA, M.R.B. , 2006. Leishmaniose visceral: situação epidemiológica e distribuição espacial, município de Palmas, Tocantins. Rio de Janeiro: Escola Nacional de Saúde Pública Sergio Arouca, Fundação Oswaldo Cruz, 86 p. Dissertação de Mestrado em Vigilância em Saúde.

GÓES, M.A.O., MELO, C.M. and JERALDO, V.L.S., 2012. Série temporal da leishmaniose visceral em Aracaju, estado de Sergipe, Brasil (1999 a 2008): aspectos humanos e caninos. Revista Brasileira de Epidemiologia, vol. 15, no. 2, pp. 298-307. PMid:22782095. http://dx.doi.org/10.1590/S1415-790X2012000200007. 
GONÇALVES, S.A., 2013. Controle do reservatório canino para leishmaniose visceral, na regional noroeste de belo horizonte, minas gerais, 2006-2011. Belo Horizonte: Universidade Federal de Minas Gerais, 67 p. Dissertação de Mestrado em Ciência Animal.

INSTITUTO BRASILEIRO DE GEOGRAFIA E ESTATÍSTICA - IBGE, 2010 [accessed 10 March 2014]. Censo 2010 [online]. Available from: http://www.ibge.gov.br/estado

KAMPHORST, A.O., ARAKI, K. and AHMED, R., 2015. Beyond adjuvants: immunomodulation strategies to enhance $\mathrm{T}$ cell immunity. Vaccine, vol. 33, suppl. 2, pp. B21-B28. PMid:26022562. http://dx.doi.org/10.1016/j.vaccine.2014.12.082.

LINDOSO, J.A.L., CRUZ, L.L., SPINOLA, R.M., FORTALEZA, C.M., NOGUEIRA, P.A. and MADALOSSO, G., 2006. Fatores associado à leishmaniose visceral grave. Revista da Sociedade Brasileira de Medicina Tropical, vol. 39, no. 3, suppl. 3, pp. 133-134. PMid:17605225.

MADALOSSO, G., FORTALEZA, C.M., RIBEIRO, A.F., CRUZ, L.L., NOGUEIRA, P.A. and LINDOSO, J.A., 2012. American visceral leishmaniasis: factors associated with lethality in the state of São Paulo, Brazil. Journal of Tropical Medicine, vol. 2012, pp. 281572. PMid:23024661. http://dx.doi.org/10.1155/2012/281572.

MALAFAIA, G., 2010. Leishmaniose visceral e desnutrição: uma relação ainda muito negligenciada. Revista da Sociedade Brasileira de Medicina Tropical, vol. 43, no. 4, pp. 478-479. PMid:20802959. http://dx.doi.org/10.1590/S0037-86822010000400033.

MIRANDA, G.M.D., 2008. Leishmaniose visceral em Pernambuco: influência da urbanização e da desigualdade social. Recife: Centro de Pesquisas Aggeu Magalhães, Fundação Oswaldo Cruz, 134 p. Dissertação de Mestrado em Saúde Pública.

MISSAWA, N.A. and BORBA, J.F., 2009. Leishmaniose visceral no município de Várzea Grande, Estado de Mato Grosso, no período de 1998 a 2007. Revista da Sociedade Brasileira de Medicina Tropical, vol. 42, no. 5, pp. 496-502. PMid:19967230. http://dx.doi.org/10.1590/S0037-86822009000500005.

OLIVEIRA, A.L.L., PANIAGO, A.M., SANCHES, M.A., DORVAL, M.E., OSHIRO, E.T., LEAL, C.R., PAULA, F.H., PEREIRA, L.G., CUNHA, R.V. and BÓIA, M.N., 2008. Asymptomatic infection in family contacts of patients with human visceral leishmaniasis in Três Lagoas, Mato Grosso do Sul State, Brazil. Cadernos de Saude Publica, vol. 24, no. 12, pp. 2827-2833. PMid:19082273. http://dx.doi.org/10.1590/ S0102-311X2008001200011.

PETER, H., 2015. Investing to overcome the global impact of neglected tropical diseases: Third WHO report on neglected diseases. Geneva: World Health Organization Press. 191 p.

PRADO, P.F., ROCHA, M.F., SOUSA, J.F., CALDEIRA, D.I., PAZ, G.F. and DIAS, E.S., 2011. Aspectos epidemiológicos da leishmaniose visceral humana e canina em Montes Claros, Estado de Minas Gerais, Brasil, entre 2007 a 2009. Revista da Sociedade Brasileira de Medicina Tropical, vol. 44, no. 5, pp. 561-566. PMid:22031070. http://dx.doi.org/10.1590/S003786822011000500006
REGUERA, R.M., MORÁN, M., PÉREZ-PERTEJO, Y., GARCÍA-ESTRADA, C. and BALAÑA-FOUCE, R., 2016. Current status on prevention and treatment of canine leishmaniasis. Veterinary Parasitology, vol. 227, pp. 98-114. PMid:27523945. http://dx.doi.org/10.1016/j.vetpar.2016.07.011.

REIS, L.L., BALIEIRO, A.A.S., FONSECA, F.R. and GONÇALVES, M.J.F., 2017. Changes in the epidemiology of visceral leishmaniasis in Brazil from 2001 to 2014. Revista da Sociedade Brasileira de Medicina Tropical, vol. 50, no. 5, pp. 638-645. PMid:29160510. http://dx.doi.org/10.1590/00378682-0243-2017.

REY, L.C., MARTINS, C.V., RIBEIRO, H.B. and LIMA, A.A.M., 2005. Leishmaniose visceral americana (calazar) em crianças hospitalizadas de área endêmica. The Journal of Pediatrics, vol. 81, no. 1, pp. 73-78. PMid:15644826. http://dx.doi.org/10.2223/1286.

SCANDAR, S.A.S., SILVA, R.A., CARDOSO-JÚNIOR, R.P., OLIVEIRA, F.H., 2011. Ocorrência de Leishmaniose visceral americana na região de São José do Rio Preto, estado de São Paulo. Brasil Bol Epidemiol Paulo, vol. 8, no. 88, pp. 13-22.

SILVA, A.R., TAUIL, P.L., CAVALCANTE, M.N., MEDEIROS, M.N., PIRES, B.N. and GONÇALVES, E.G., 2008. Situação epidemiológica da leishmaniose visceral, na Ilha de São Luís, Estado do Maranhão. Revista da Sociedade Brasileira de Medicina Tropical, vol. 41, no. 4, pp. 358-364. PMid:18853007. http:// dx.doi.org/10.1590/S0037-86822008000400007.

SILVA, A.V.M., PAULA, A.A., CABRERA, M.A. and CARREIRA, J.C., 2005. Leishmaniose em cães domésticos: aspectos epidemiológicos. Cadernos de Saude Publica, vol. 21, no. 1, pp. 324-328. PMid:15692667. http://dx.doi.org/10.1590/ S0102-311X2005000100036.

SILVEIRA, L.J.D., ROCHA, T.J., RIBEIRO, S.A. and PEDROSA, C.M., 2015. Historical series of patients with visceral leishmaniasis treated with meglumine antimoniate in a hospital for tropical diseases, Maceió-AL, BRAZIL. Revista do Instituto de Medicina Tropical de Sao Paulo, vol. 57, no. 1, pp. 33-38. PMid:25651324. http://dx.doi.org/10.1590/S0036-46652015000100005.

SISTEMA NACIONAL DE INFORMAÇÃO SOBRE SANEAMENTO - SNIS, 2012 [accessed 12 June 2016]. Sistema Nacional de Informação sobre Saneamento (SNIS-2012) [online]. Available from: http://www.snis.gov.br.

SOUZA, Z.C., BRANDESPIM, D.F., AGRA, M.C.R. and SIMÕES-MATTOS, L., 2014. Leishmaniose visceral canina e humana em Caruaru, Pernambuco, no período de 2005 a 2010. Revista de Patologia Tropical, vol. 43, no. 1, pp. 57-68. http:// dx.doi.org/10.5216/rpt.v43i1.29372.

XAVIER-GOMES, L.M., COSTA, W.B., PRADO, P.F., OLIVEIRA-CAMPOS, M. and LEITE, M.T.S., 2009. Características clínicas e epidemiológicas da leishmaniose visceral em crianças internadas em um hospital universitário de referência no norte de Minas Gerais, Brasil. Revista Brasileira de Epidemiologia, vol. 12, no. 4, pp. 549-555. http://dx.doi.org/10.1590/S1415$790 \times 2009000400005$. 